\title{
FOREST ECONOMY VERSUS SUSTAINABLE DEVELOPMENT
}

\author{
Małgorzata Falencka-Jabłońska' \\ 1 Department of Forest Ecology, Forestry Research Institute, Braci Leśnej Str. 3, 05-090 Raszyn, Poland, \\ e-mail: falenckm@ibles.waw.pl
}

Received: 2017.09.03

Accepted: 2017.10.01

Published: 2017.11.01

\begin{abstract}
2017 marks the 30 years since the The World Commission on Environment and Development has published the Brundtland report "Our common future". The documents of III Ministerial Conference on the Protection of Forests in Europe and the notations of 1.2 resolution adopted in Lisbon have obliged Poland to run forest management according to the rules of lasting and sustainable development. The forest economy was based on a multi-use forest model with special attention devoted to its environmentcreating and social role. The actions which confirmed the introduction of rules of sustainable development into forest practice included: creating 19 Promotional Forest Complexes, systematic increase of afforestation and number of reserves. Designation of Natura 2000 areas in Poland within European Network of Protected Sites was also a very important element. Amongst those areas, as much as $39 \%$ are forest ecosystems.
\end{abstract}

Keywords: Promotional Forest Complexes, Natura 2000 Areas, sustainable development, forest management

\section{INTRODUCTION}

Anthropic pressure is a long-term process of systematically increasing influence of a human and his activity on the surrounding nature. Particularly distinct negative effects of industrial impact on environment were observed over the course of past 200 years. Dynamic economic and civilization development caused that the industrial emissions and their accumulation governed the pace of environment degradation, not only on the areas close to industrial plants (FalenckaJabłońska 2006, Falencka-Jabłońska 2013).

Forests belong to the most complex terrestrial ecosystems; therefore, they have always been a sensitive indicator of imbalances and negative changes in the environment.

It is worth noting that the first publication referring to forest damages incurred as a result of industrial emissions on the Polish ground was published in German at the end of the $19^{\text {th }}$ century (Reuss 1893). The author, who was a chief forester at the time, calculated that the measurable loss incurred as a result of "smoke damages" on the area of Katowice-Mysłowice forest inspectorate with a total area of $3500 \mathrm{ha}$, amounted to as much as 200.000 marks (Łuczkiewicz 1922a).

In the cycle of his articles, the author also noticed that the more tree species are adapted to the habitat, the more resistant they are to the smoke influence. Already then, he demanded to implement the legal protection of forests and pass the "air law" which would define the permitted concentration of toxic substances in the air and present effective products limiting its formation (Łuczkiewicz 1922 b,c,d).

In the years of the biggest pressure of industrial emissions on forests, i.e. in the $70 \mathrm{~s}$ and $80 \mathrm{~s}$ of the previous century, the evaluation of loss in the increment of wood mass was made on the following levels: in zone I of emissions impact it was $20 \%$, in zone II $-40 \%$ and in zone III even up to $55 \%$. On the other hand, in so called zero zone it was calculated on lower level than $20 \%$. It should also be emphasized that when the degree of forest cover is considered, the loss in the increment were significantly higher, and so: in zone I it was $25 \%$, in zone II $49 \%$ and in zone III even $75 \%$ (Greszta 1975). 
The degree of environment contamination was a reflection of the amount of emitted pollution. The data from the half of the 1980s indicate that in our country over 5 million tons of gas pollution was emitted into the atmosphere. According to the data from the Central Statistical Office, around 7 thousands industrial plants were responsible for this contamination and amongst them 1100 were the most oppressive ones, responsible for $90 \%$ of global emission. This group also included 77 industrial plants belonging mainly to iron and steel, energy and chemical industry which emitted, at the time, as much as $77 \%$ of total gas emission that threatened the natural environment (Rudzki 1985).

The Polish industry, at the turn of $20^{\text {th }}$ and $21^{\text {st }}$ century, had emitted around 3 million tons of $\mathrm{SO}_{2}$ which influence placed our country amongst other top polluting countries in Europe. Due to dominant direction of western winds, around 1.5 million tons of $\mathrm{SO}_{2}$ from Germany and Czech Republic additionally reached our territory each year (Falencka-Jabłońska 2013).

The current Polish law regulation on environmental protection and their systematic adjustment to formal requirements applicable in the countries of the EU and conditions resulting from Poland's ratification of international conventions, influence the necessity of systematic reduction of industrial emissions. By signing the resolution 1.2, which was adopted in Lisbon in 1998 on III Ministerial Conference on the Protection of Forests in Europe, Poland was obliged to run forest policy and management on rules of sustainable development. The criteria of this resolution were included in the guidelines of the discussed document and explicitly define, inter alia, the necessity of maintenance:

- and proper increasing of forest resources and their contribution in global carbon cycle,

- of health and vitality of forest ecosystems,

- and protection and increase of the bio-diversity in forest ecosystems

Treating forest as a complex system of dependence between components is not an approach developed in the last decades of $20^{\text {th }}$ and $21^{\text {st }}$ century. Józef Paczoski (1896) - a creator of phytosociology- science of plant communities, put it that way: "Forest differentiates space in ways no other plant community can. Soil and air are changed not only to depth reached by the roots and to the height reached by the crowns, but also in the adjoining layers. The air space occupied by forest is filled with a mass of trunks, boughs, branches and leaves, while often all this tends to be divided to more or less independent layers, each of different illumination, temperature, humidity degree and therefore biologically diversified. All this creates, in comparison to other plant communities, a great diversity and variety. It is manifested peculiarly in old forest in which found can be dead, withering and hollow trees that offer food and shelter for whole groups of animals..." (1925),

Archival documents and maps drawn up on their basis constitute a clear evidence that in year 900 , forests covered almost $80 \%$ of our entire continent. Despite the fact that forest exploitation had its beginning in the Roman times, a significant decrease in forest coverage was noted already in the $19^{\text {th }}$ century. Firstly, this phenomenon occurred in southern Europe and then it was present also in the middle Europe. Only at the beginning of the $20^{\text {th }}$ century, people realized that deforestation of large areas carries long-range negative effects and not only for the nature.

\section{SUSTAINABLE DEVELOPMENT AND IMPLEMENTATION OF ITS PRINCIPLES IN POLISH FORESTS}

Thirty years ago, in April 1987, The World Commission on Environment and Development has published a well-known report "Our Common Future". The concept of sustainable development was included in this report.

The contents of this document indicated explicitly that the current level of prosperity of our, civilization, which is concentrated on consumption, can only be maintained if our approach to the economy and the will for preserving nature resources changes. According to this document, sustainable development guarantees economic growth only with respect for nature resources and care about future generations.

It should be emphasized that the term "sustainable development" was introduced for the first time by Hans Carl von Carlowitz who was a Saxon district governor. He used this term in a field of forestry. Germany lacked wood because of decimation of local forests at the beginning of $18^{\text {th }}$ century. In 1713, H.C von Carlowitz ordered a reconstruction of forests subjected to him and introduced the rules of regulated and forward-looking proceedings with natural resources. Soon, his model was adopted in the forestry of entire Ger- 
many and then became an example for the whole world (Falencka-Jabłońska, Małecka 2016).

In Poland, the sustainable development in accordance with principles from 1987 report gained a constitutional rank. It was bequeathed in article 5 of the Constitution of the Republic of Poland and the sustainable development definition was included in the environmental law.

This notion should be understood as: a socialeconomic development in which the process of integration of policy, economic and social actions occurs with maintaining environmental balance and permanence of natural processes for guaranteeing the possibility of satisfying basic needs of particular communities or citizens of both current and future generations.

\section{WHAT DO WE HAVE AT OUR DISPOSAL?}

After Word War II the forest area increased gradually. During the last several years the area of European forests has increased by 13 million hectares. It is an effect of afforestation and natural succession on former agricultural areas. At the same time, wood resources have increased significantly. The current wood supply, on the continental scale, amounts to around 112 billion $\mathrm{m}^{3}$ and has increased since the last 15 years by 358 million $\mathrm{m}^{3}$. This value constitutes around $16 \%$ of entire wood mass of our country.

In the historical past, large complexes of virgin forests and extensive wetlands and swampy areas dominated in our Polish landscape. As agriculture and the need for wood raw material developed, the afforestation of our country dropped and thus: one thousand years ago it amounted almost to $70 \%$ and in 1820 it was only 38\%. After World War II and wasteful exploitation of forest, it reached its lowest level in the history, i.e. $20.8 \%$. After World War II, thanks to the efforts and painstaking work of foresters, an increase in the size of forest area occurred. It was caused mainly by a systematically run afforestation. Presently, the forest area constitutes over $29 \%$ of country's area and the goal is to reach 30\%. Currently, the area of forest per one statistical inhabitant in Poland amounts 0.24 ha and this value is one of the lowest in the region. It is estimated that the average European forest cover is around 30\%. The top countries in terms of forest resources are: Finland (72\%) and Sweden (57\%), whereas
Ireland (9\%) and Denmark (10\%) have the least forests (tab. 1).

Our country is a leader, not only in Europe, in terms of the indicators evaluating biological diversity (according to the guidelines in Convention on Biological Diversity - one of final documents of Earth Summit in Rio de Janeiro in 1992). The analyzed levels of biological diversity: genetic, species, ecosystem and landscape, prove that Poland has unique resources and nature qualities which are worth highest protection status. Certain studies (Grzywacz 1995) indicate that as much as $65 \%$ of this diversity, i.e. over 32000 species, is located in forest ecosystems.

An important role is played by special forest stands on the total area of 226.860 ha which constitute a seed base. They consist of plus seed stands (16.033 ha) and temporary seed production stands (207.621 ha) thanks to which it is possible to choose native ecotypes of greenwoodogenic species (data: Report on the state of forests in Poland 2014).

\section{PROMOTIONAL FOREST COMPLEXES}

Within introducing policy regarding sustainable forest management (SFM), 19 Promotional Forest Complexes and Conception of Polish Promotional Forest Complex (PFC) were established. They were introduced in 1990. PFC has become pioneers in pro-ecological forest management re-

Table 1. Forests in Europe (2014)

\begin{tabular}{|l|c|c|}
\hline \multicolumn{1}{|c|}{ Country } & $\begin{array}{c}\text { Forest area (mln. } \\
\text { ha) }\end{array}$ & Afforestation (\%) \\
\hline Austria & 3.88 & 50 \\
\hline Belgium & 0.62 & 30 \\
\hline Denmark & 0.46 & 10 \\
\hline Finland & 20.11 & 72 \\
\hline France & 13.06 & 33 \\
\hline Greece & 2.51 & 25 \\
\hline Spain & 8.39 & 21 \\
\hline Holand & 0.33 & 10 \\
\hline Ireland & 0.39 & 9 \\
\hline Germany & 10.74 & 31 \\
\hline Poland & 9.3 & 29.1 \\
\hline Portugal & 2.72 & 38 \\
\hline Sweden & 24.44 & 57 \\
\hline Great Britain & 2.21 & 11 \\
\hline Italy & 6.75 & 29 \\
\hline
\end{tabular}


alization and an example which was worth copying for other Polish forests. Their functioning clearly proves the possibility of bringing together forest management with a multi-use forest, which allows for its environment-creating role and also very significant social functions.

\section{NATURE PROTECTION}

In our country, for the past several years, rezalized was so-called multiple use forest model. The idea is to use the forest according to lasting and sustainable development of forests and forestry. In practice, it means that all functions of this complex terrestrial ecosystem were given a proper rank. Therefore, forests and their components are the most valuable nature qualities which were covered with special protection.

Economists from the University of Warsaw have made an interesting calculation and comparison according to which the price of raw material in one of Polish National Parks amounts to $500 \mathrm{PLN} /$ ha, while non-production functions of this forests are evaluated for 4.076PLN which is eight times more.

In 23 National Forests, the forest coverage constitutes $62 \%$. In the existing 1451 reserves, forest areas constitute around $64 \%$, according to Central Statistical Office. On the basis of prov- ince governor decision 121 landscape Parks where forest areas constitute over 50\% were established so far.

According to "National Strategy on conservation and sustainable use of biodiversity" for years 2007-2013, 200 new reserves of joint area of 20.000ha were planned. Data indicates that in year 2007-2016, 99 reserves were established in our country. Most of them, i.e. 31, were established in Zachodniopomorskie voivodeship, whereas in Mazowieckie and Pomorskie - 13 reserves in each. In the last decade, no reserve was established in Łódzkie voivodeship. In each of the three voivodeships: Dolnośląskie, Podlaskie and Kujawsko-Pomorskie, a single reserve was established (Figure 1)

In Łódzkie voivodeship, the last reserve was established 11 years ago. The biggest threats for biodiversity are assumed to be: progressive fragmentation of habitats and ecosystems, simplification of habitat mosaic, flora and fauna synanthropisation, permeation of foreign and modified genetically species into natural, ecological system and their uncontrolled spread (FalenckaJabłońska et al. 2005).

In reference to this situation in forest management, the following actions were included : rational environmental basis, protection and moderate use of biodiversity in management procedures, protection and forest management.
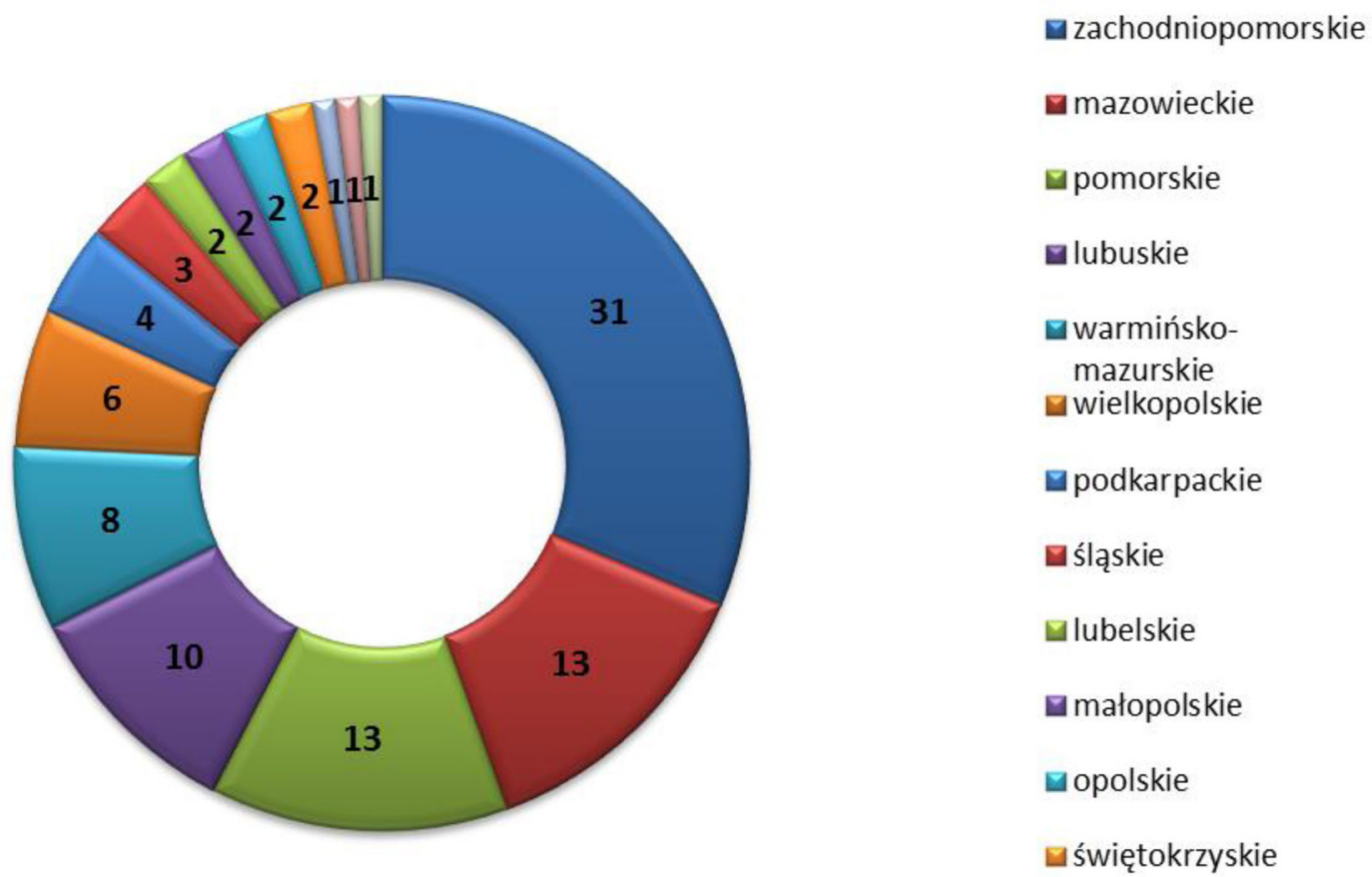

Figure 1. The number of newly established reserves in years 2007-2016 
In terms of the history of nature protection and forest management, three periods should be distinguished:

- The period to the beginning of $19^{\text {th }}$ century in which forest exploitation dominated and nature protection had a marginal meaning,

- The period from the second half of $19^{\text {th }}$ century when the beauty of nature was the decisive factor for the protection of its monuments. Hugo Convents was the promoter of this idea, owing to his initiative, a yew-tree reserve was established in Wierzlas and urban forests reserves in Gdańsk and Toruń,

- The period from the 1960 until today. A beginning of this period was U'Thant's report that drew attention of world's societies to the threats resulting from the increase of the pollution degree in the natural environment.

Change in perception of nature protection in forests has its reflection in the comparison e.g. of remaining dead wood in forests. The amount of dead wood in Poland is presently $6 \mathrm{~m}^{3} / \mathrm{ha}$ and is very similar to such countries like Sweden or Belgium. The comparison of the numbers below is also relevant:

- Biosphere Reserves (UNESCO program: Man and the Biosphere, MAB) in $1989-3$ and in $2009-8$

- Wetland-swampy areas of international meaning (Ramsar Convention) there were none in 1989 and in 2009 there are 7.

- Areas awarded with European diploma for protected areas (The Council of Europe) in 1989 there was none, in $2009-2$.

There were around 1000 reserves in Poland in 1989 and their joint area amounted to 117 thousand hectares. In 2010, there were almost 1.200 reserves of joint area of 120 thousands hectares on the area of the State Forests. At the same time, Natura 2000 program covers 417 forest inspectorates of the joint area equal to 2.5 million hectares.

The influence of society on forming the role of forest were reflected in Ordinance no.12 of General Director of the State Forests from 27 January 2009, which defined the procedures of creating the forest management plan with increased share of society's opinion, and also Ordinance no. 8 from 27 January 2010 of General Director of the State Forests on rules and mode of sharing information by the State Forests National Forest Holding.
The former conservator's approach to nature protection was replaced by an active nature protection which does not only refer to protection of given species but also habitat conditions that provide its survival. All this remains in close relation to rules of durable and sustainable development which combines nature protection with rational use of its resources.

An illustration of that can be a comparison of number of protected species in the last halfcentury in Poland:

- 1957 - with strict protection covered were 39 species and with partial - 15 species,

- 2001 - with strict protection covered were 246 species and with partial - 72,

- 2004 - with strict protection covered were 584 species where 109 of them requires active protection, with partial protection covered were 58 species where 14 species is acceptable for collecting, 10 species requires creating protection zones.

\section{NATURA 2000 AREAS}

Our forests play also an important part and have its share in introducing rules of sustainable development in the European network of areas of Natura 2000 program. The legal basis for its functioning comprises two EU's Directives - Birds and Habitats. Therefore, two categories of Natura 2000 network areas were designated:

- Special Protection Areas (SPAs), designated for the protection of populations of wild feathered game,

- Special Areas of Conservation (SACs), designated for the protection of habitats of great natural value and plants and animals occurring there

Presently, there are 142 SPAs and 817 SACs in Poland. Natura 2000 areas constitute altogether $19.3 \%$ of our country's area. Forest areas constitute $38 \%$ of total Natura 2000 areas. SPAs are located on State Forest's land in $29 \%$. which is an area of 2.2 million ha and SACs are located on $15 \%$ State Forest's land which is 1.1 million hectares. Natura 2000 covered 417 forest inspectorates. (data: Report on the state of forests in Poland 2014). 


\section{CONCLUSIONS}

Sustainable development in the field of forest economy is introduced through:

- Creating Promotional Forest Complexes (19),

- Covering $38 \%$ of forest area with Natura 2000 European Network,

- Systematic increase of country's afforestation,

- Establishing new landscape parks and reserves.

\section{REFERENCES}

1. Falencka-Jabłońska M. 2006. Synteza 30-letnich kompleksowych analiz wpływu Elektrowni „Kozienice" na środowisko leśne. W: Ochrona powietrza w teorii i praktyce (red. J. Konieczyński)- II:67-78. Instytut Podstaw Inżynierii Środowiska, Zabrze.

2. Falencka-Jabłońska M. 2013. Zmiany ekosystemów w zasięgu oddziaływania Elektrowni "Kozienice" synteza 40letnich badań interdyscyplinarnych. Prace IBL Rozprawy i Monografie 20, 304 ss.

3. Falencka-Jabłońska M., Małecka M., Skorupski M,. Rachwald A. i in. 2005. Różnorodność biologiczna jako wskaźnik procesów i zmian ekosystemów leśnych w zrównoważonym zagospodarowaniu lasów Dokumentacja IBL. 220 ss.
4. Greszta J. 1975. Wpływ immisji na siedliska borowe i drzewostany sosnowe w ŚląskoKrakowskim Okręgu Przemysłowym. Zakład Ochrony Przyrody PAN, PWN, Warszawa-Kraków.

5. Grzywacz A. 1995. Ochrona różnorodności biologicznej w zrównoważonej gospodarce leśnej. Materiały Sympozjum PTl, IBL. Warszawa.

6. Krajowa strategią ochrony i zrównoważonego użytkowania różnorodności biologicznej 2007-2016

7. Łuczkiewicz W. 1922a. Kilka słów o szkodach dymowych w okolicy Katowic Sylwan VIIIIX:195-198 Lwów.

8. Łuczkiewicz W. 1922b. Wpływ dymów fabrycznych na drzewostany Sylwan IV: 84-87 Lwów.

9. Łuczkiewicz W. 1922c. Wpływ dymów fabrycznych na drzewostany Sylwan V: 103-106 Lwów.

10. Łuczkiewicz W. 1922d. Wpływ dymów fabrycznych na drzewostany Sylwan VI: 131-137 Lwów.

11. Raport o stanie lasów w Polsc 2014. Centrum Informacyjne Lasów Państwowych, Warszawa.

12. Reuss C. 1893. Rauchbeschandigung in den von Teile Winklerschen Forstrevier Myslowitz-Katowitz.

13. Rudzki K. 1985. Czy stać nas na dalsze niszczenie lasów? Referat w ramach posiedzenia Rady NOT oraz Stowarzyszenia Inżynierów i Techników Leśnictwa i Drzewnictwa, 10 grudzień, Warszawa. 